\title{
Rheumatoid arthritis of the robust reaction type
}

\author{
W. H. D. DE HAAS, * W. DE BOER, $\dagger$ F. GRIFFIOEN, $\dagger$ AND P. OOSTEN-ELST $\ddagger$ \\ From the University of Amsterdam and the Amsterdam Centre for Rheumatic Diseases
}

Louis Pasteur (1873): 'C'est ainsi que, suivant les constitutions et les tempéraments, les maladies... atteignent ceux qui sont prédisposés à les contracter'§

In the course of 6 years a group of patients was isolated who were characterized by a curious discrepancy. On the one hand they showed a robust personality and a practically infinite capacity for work, but on the other hand they presented two unfavourable features, viz. substantial subcutaneous nodules (often the reason for referral) and a high titre in the Rose test. This type of reaction to rheumatoid arthritis has been tentatively called the robust type (Figs 1,2). The present paper reports a study of some further properties seen in this type of patient.

\section{Patients"}

Nine male patients were studied in detail. All were married men, belonging to the working class. Their mean age was $56.5 \mathrm{yrs}$ and the mean duration of their disease 9 yrs. All had classical rheumatoid arthritis with no concomitant disease, and none had been treated with corticosteroids or surgery. All were known to us for at least 2 years.

\section{Results}

(1) GENERAL IMPRESSION

All patients gave an impression of vitality and energy. Their freedom of motion seemed unaffected and lacked the slow and guarded pattern typical of rheumatoid arthritis.

The joints were, or at some period had been, moderately painful, but only rarely and briefly hab some patients had to stop work. Joints of the shouldef girdle were affected in all patients. There was ne evidence of neuropathy or vasculitis.

Subcutaneous nodules were present at the elbows in all patients and in three cases also on the fingers;

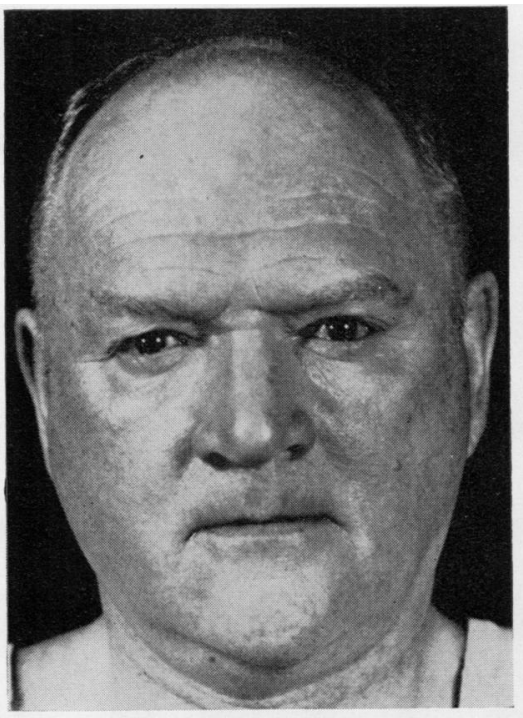

(a)

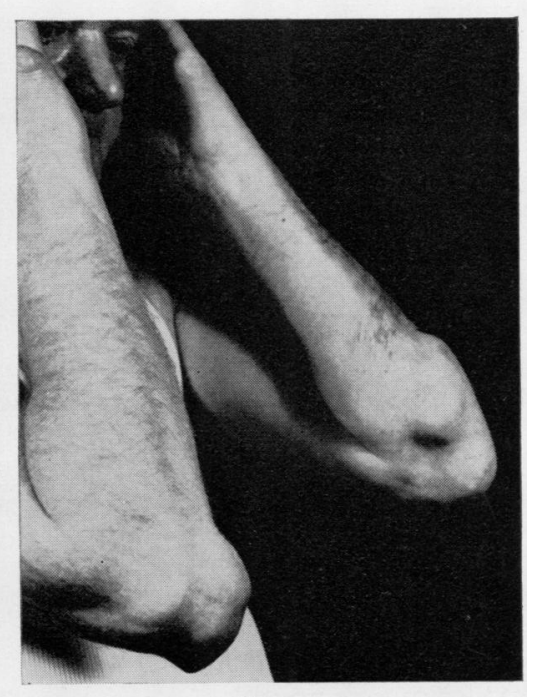

(b)
FIG. $1 a, b$ Male robust type; 54-year-old owner of $\overline{\mathrm{O}}$ plumber's shop. Never absent from work. Nodules discovered on routine examination. Refuses treatment. Rose test 1:512

Accepted for publication May 3, 1973

* Out-patient Department of Rheumatology, University of Amsterdam, and Amsterdam Centre for Rheumatic Diseases. $\uparrow$ Department of Human Biology and Human Genetics, University of Amsterdam.

₹ Psychologist, Amsterdam Centre for Rheumatic Diseases.

$\$$ 'Oeuvres de Pasteur' (1922) vol. 3, p. 161. Masson :Paris.

The group now totals fifteen patients. 


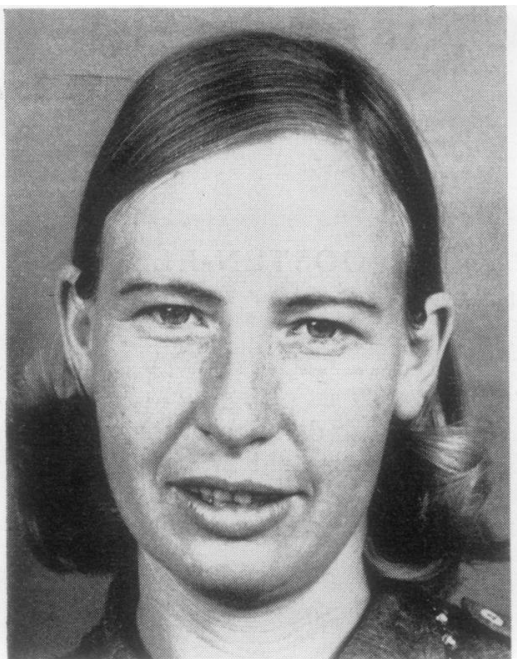

(a)

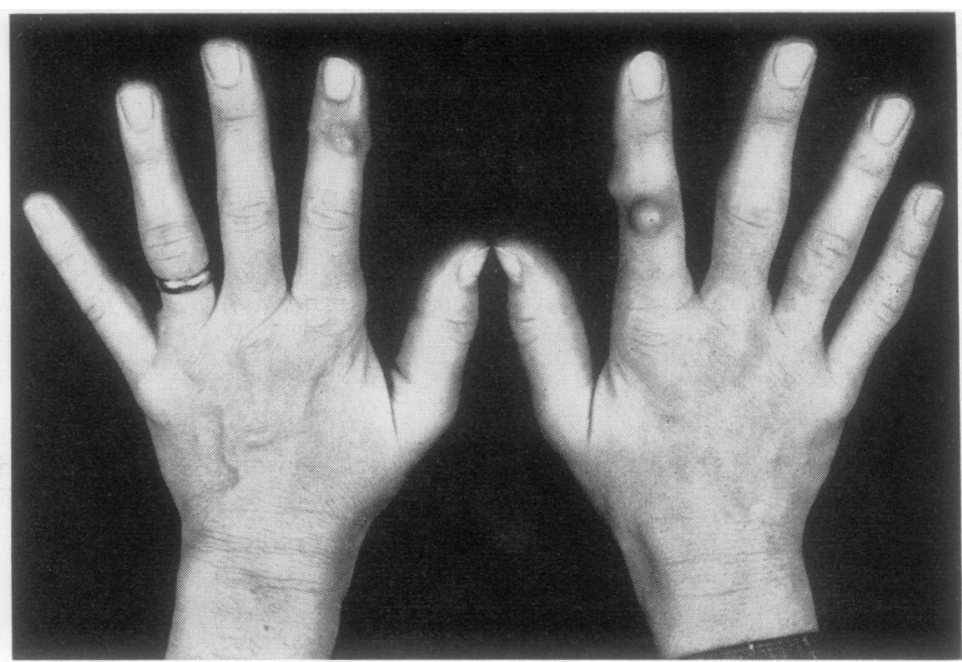

(b)

FIG. 2a, $b$ Female robust type. 30-yr-old housewife with two children, working half-time as a hospital nurse. Referred by surgeon: biopsy of finger nodule unexpectedly revealed rheumatoid arthritis. Rose test 1:256

they varied in size from a pea to a walnut and were often very firm on palpation, although in one patient they had liquefied. Nodules removed from the elbows and fingers of two patients showed typical histological changes.

\section{(2) LABORATORY FINDINGS}

Urine analysis and blood counts were normal. Five patients had a normal erythrocyte sedimentation rate. The titre of the Rose test ranged from 1:64 to $1: 1,024$; five patients had a titre of $1: 1,024$.

Quantitative immunoelectrophoresis (Dr. ReerinkBrongers) showed the mean immunoglobulin level to be rather low, but within the normal range (mean IgA 316, IgG 924, IgM 132 mg. per cent.).

\section{(3) PHYSIQUe}

The mean stature did not differ from the average for Dutch men of the same age. It was further analysed by somatotyping according to Sheldon, Dupertuis, and McDermott (1954). In addition to this somatoscopic method, the anthropometric method described by Heath and Carter (1967) was used; the results with both methods were in good agreement. It was found that eight of the nine patients were mesomorphs (athletics), the exception being an endomorph with a distinct mesomorph component. In all, the score for endomorphia was moderately high and the ectomorphic score very low. In control groups of patients with rheumatoid arthritis no Sheldon type prevailed.

\section{(4) RADIOLOGY}

Osteoporosis and moderately large erosions were present in all patients, but none had large cysts or 'geodes'. In the long bones the cortex was of normal thickness. The sacroiliac joints were normal. The findings thus were not different from those to be found in the average patient with moderately severe rheumatoid arthritis.

\section{(5) FUNCTION}

The grip strength showed an average of $324 \mathrm{~mm} . / \mathrm{Hg}$ in the right hand and $290 \mathrm{~mm}$./ $\mathrm{Hg}$ in the left (in normal subjects these values range from 450 to 600 , compared with 30 to 200 in cases of active rheumatoid arthritis. Patients in remission show about the same grip strength as the robust type).

Eight of the nine patients did heavy manual work, and the other owned an ice factory. Some of these patients, though over 50 years old, continued to play games.

A dolorimetric study was done with the instrument described by McCarty, Gatter, and Phelps (1965). Measurements were performed on all interphalangeal joints (except those of the thumbs) and also on the shins and earlobes; the results were compared with those in 100 normal controls. The pain threshold (Fig. 3 , opposite) in the proximal interphalangeal joints fluctuated around the average of normal subjects, but in the distal interphalangeal joints it was clearly increased. The threshold on both shins and earlobes showed no difference from normal.

\section{(6) USE OF ANALGESICS AND OTHER TREAT- MENT}

Few patients were taking analgesics. Four did not subject themselves to any treatment at all; the remainder had more or less been pressed to undergo maintenance gold therapy. 


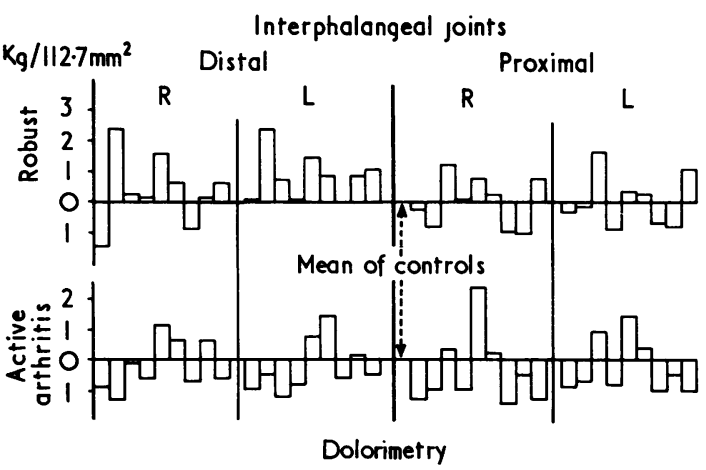

FIG. 3 The horizontal line marks the mean of 100 normal controls for each joint.

Each column represents the mean value of the pressure, above or below the normal level, eliciting pain in the four adjacent interphalangeal joints in the right or left hand of each patient. Threshold measured in $\mathrm{kg} .1112 .7 \mathrm{~mm}^{2}$. Upper histogram: robust patients. Lower histogram: results in nine matched patients with active rheumatoid arthritis

\section{(7) PSYCHOLOGY}

All patients were subjected to a psychological interview and a neuroticism test. Special attention was focused on suppressed hostility, exploitation of disease-induced dependence, and introvert behaviour. Resistance to frustrating environmental influences and initiative were also noted.

Though hostile tension was found to be present in four patients (an incidence comparable to that found in rheumatoid patients in general), disease exploitation was completely lacking and all patients were extroverts. Mental stolidity was well developed. All patients were initiative minded. Six had their own business and only three were employed. Results were not related to I.Q. For the neuroticism score, the Dutch A.B.V. test (Wilde, 1963) was used (closely resembling the British Maudsley Personality Inventory, Jensen, 1958). Whereas patients suffering from active rheumatoid arthritis tend to have a high score (up to 8 , i.e. unfavourable), the robust patients all had a normal score (mean 5.7).

\section{Discussion}

A special clinical profile of rheumatoid arthritis could be determined by factors inherent in the patient, in the disease, or in the environment.

The patients were of an athletic type, uncommon in rheumatoid arthritis. Though their grip strength had suffered, they were able to work normally.

Their mental make-up was also striking. Unlike most rheumatoid arthritis patients (Prick, 1964; Du Bois, 1971; Moldofsky and Chester, 1970; Moldofsky and Rothman, 1971; Bloch and Schild, 1971; Ward, 1971; Friedman, 1972; Robinson,
Kirk, Frye, and Robinson, 1972; Wolff, 1972), they were sthenic individuals, whose sense of initiative had made them their own masters. Their pain threshold, normal outside the joints (as in all rheumatoid arthritis patients, Huskisson and Hart, 1971), showed a distinctive tendency to be raised at the finger joints.

The disease presented only quantitative features to distinguish it from normal rheumatoid arthritis. Subcutaneous nodules are mainly the consequence of the use made of the limbs and thus their presence in the robust patients, who did not spare themselves, could be explained. Corresponding radiological changes, namely the 'geodes' described in patients continuing manual labour (Bywaters, 1964; Castillo, El Sallab, and Scott, 1965; Jayson, Dixon, and Yeoman, 1972), were absent (as also reported by Huskisson and Hart, 1971). As to the high titre of the Rose test, one might speculate on the possibility of an increased amount of rheumatoid factor passing in the blood by chronic traumatization of the nodules, which are among the loci in which the factor is demonstrated and probably produced (Mellors, Heimer, Corcos, and Korngold, 1959). The pattern of the immunoglobulins, sometimes seen to be unusual in such variants as juvenile (Bianco, Panush, Stillman, and Schur, 1971; Panush, Bianco, and Schur, Rocklin, David, and Stillman, 1972), senile (Heimer, Levin, and Rudd, 1963), and psoriatic arthritis (Tapanes, Rawson, and Hollander, 1972), or in patients under stress (Hendrie, Paraskevas, Baragar, and Adamson, 1971), did not differ in our patients from the levels ordinarily seen in rheumatoid arthritis.

Environmental circumstances are difficult to evaluate, but they appeared to be normal in our patients.

Robust type rheumatoid arthritis represents a special reaction to the disease of a strong body supported by a tough mind, but is in no other way a separate clinical entity. This type of reaction has attracted little attention. Solitary cases are described in the literature as 'goutlike rheumatoid arthritis' or as 'rheumatismus nodosus' in cases in which many nodules were present, or as patients with an 'isolated' high titre in the Rose test (Svartz, 1971; Waller, 1968) in cases having little or no disease of the joints.

What is primary and what secondary? Does the robust patient dominate a 'normal' disease by his vigorous constitution? Or is it that the disease is of a 'mild' type and less damaging to a 'normal' patient? Is an independent-minded patient by that very quality driven to hold on to his work? Or is the work-minded patient maintaining his independence as a sort of by-product of his industrious character? These, and some other problems inherent in this study, are of the chicken and egg type; various different factors undoubtedly play a role. 


\section{Therapeutic consequences}

Though robustness is an innate condition, the question must be raised whether a suitable category of patients should not be encouraged to accomplish, under medical supervision, what the robust patients have achieved without it. Treatment, apart from typical antirheumatic therapy, would aim at general locomotor training. This idea, of course, is not new. In fact, it was already advocated by Asclepiades 2,000 years ago (Licht, 1969), and indications of a similar tenor can be found in the recent literature (Holt, 1969; Sichère and Huckel, 1971; Congress, 1972).

In our department we have started group therapy for ten moderately affected men, including general gymnastics, respiratory exercises, light ball games and swimming in a heated pool. The first results are gratifying. No systemic reaction has occurred; the erythrocyte sedimentation rate surprisingly has a distinct tendency to decrease. The thoracic excursion and the grip strength have improved. The patients feel better and wish to continue this treatment.

\section{Summary}

An account is given of a group of nine male patients with classical rheumatoid arthritis with a striking discrepancy in common. On the one hand they had the prognostically unfavourable symptoms of subcutaneous nodules and a high titre of the Rose test, while, on the other hand, they were robust, felt well, and were working normally. This condition has been designated 'robust type rheumatoid arthritis'. In an attempt to determine the factors causing this unusual course of the disease, the group was subjected to a study which revealed additional sthenic properties: an athletic build, good grip strength, high pain threshold in the finger joints, mental stolidity, and independence. The patients were capable of maintaining an independent social position. Their attitude of ignoring or shrugging off the disease, though aggravating some symptoms, did not seem to be detrimental to the state of the joints or to their general condition, and it was of distinct benefit to their morale. The question is raised whether an improvement in the physical and mental condition of 'ordinary' patients could have an equally favourable result.

\section{References}

ASCLEPIADES, 100 B.C. (Cited by S. H. Snorrason in Licht, 1969)

Bianco, N. E., Panush, R. S., Stillman, J. S., AND Schur, P. H. (1971) Arthr. and Rheum., 14, 685 (Immunologic studies of juvenile rheumatoid arthritis)

Bloch, C., AND Schild, R. (1971) Schweiz. med. Wschr., 101, 304 (Wie erlebt der Rheumatologe die psychischen Probleme seiner Patienten?)

Bywaters, E. G. L. (1964) 'The hand' in 'Radiological Aspects of Rheumatoid Arthritis'. International Congress Series, No. 61, p. 43. Excerpta Medica Foundation, Amsterdam

Castillo, B. A., El Sallab, R. A., AND Scott, J. T. (1965) Ann. rheum. Dis., 24, 522 (Physical activity, cystic erosions, and osteoporosis in rheumatoid arthritis)

CONGRESS LICHAMELIJK GEHANDICAPTEN EN DE SPORT (1972) Report in Technische Gids, 41, 415 (Sportbeoefening dient onderdeel uit te maken van revalidatie- en sociale begeleidingsprogramma's)

Du BoIs, R. (1971) Praxis, 60, 747 (Aspects psychosomatiques de l'arthrite rhumatoide)

Friedman, H. (1972) Acta psychiat. belg., 72, 117 (Aspects psychosomatiques de la polyarthrite chronique évolutive ou polyarthrite rhumatoìde)

Heath, B. H., AND Carter, J. E. L. (1967) Amer. J. Phys. Anthrop., 27, 57 (A modified somatotype method)

Heimer, R., LeVIN, F. M., AND Rudd, E. (1963) Amer.J. Med., 35, 175 (Globulins resembling rheumatoid factor in serum of the aged)

Hendrie, H. C., Paraskevas, F., Baragar, F. D., and Adamson, J. D. (1971) J. psychosom. Res., 15, 337 (Stress, immunoglobulin levels, and early polyarthritis)

HoLt, P. J. L. (1969) Brit. med. J., 3, 514 (Management of rheumatoid arthritis)

Huskisson, E. C., AND Hart, F. Dudley (1971) Méd. et Hyg., 29, 2054 (Seuil de la douleur et arthrite)

Jayson, M. I. V., Dixon, A. St. J., AND Yeoman, P. (1972) Ann. rheum. Dis., 31, 174 (Unusual geodes ('bone cysts') in rheumatoid arthritis)

Jensen, A. R. (1958) Acta psychol. (Amst.), 14, 314 (The Maudsley Personality Inventory)

Licht, E. (1969) 'Arthritis and Physical Medicine', p. 196. New Haven, Conn.

McCarty, D. J., GatTer, R. A., AND Phelps, P. (1965) Arthr. and Rheum., 8, 551 (A dolorimeter for quantification of articular tenderness)

Mellors, R. C., Heimer, R., Corcos, J., AND Korngold, L. (1959) J. exp. Med., 110, 875 (Cellular origin of rheumatoid factor)

Moldofsky, H., AND Chester, W. J. (1970) Psychosomat. Med., 32, 309 (Pain and mood patterns in patients with rheumatoid arthritis)

— AND Rothman, A. I. (1971) J. chron. Dis., 24, 363 (Personality, disease parameters, and medication in rheumatoid arthritis)

Panush, R. S., Bianco, N. E., Schur, P. H., Rocklin, R. E., David, J. R., and Stillman, J. S. (1972) Clin. exp. Immunol., 10, 103 (Juvenile rheumatoid arthritis, cellular hypersensitivity, and selective IgA deficiency) 
Prick, J. G. G. (1964) 'The Psychosomatic Approach to Primary Chronic Rheumatoid Arthritis'. Van Gorcum, Assen, The Netherlands

Robinson, H., KIRK, R. F., FrYe, R. F., AND RoberTson, J. T. (1972) J. psychosomat. Res., 16, 53 (A psychological study of patients with rheumatoid arthritis and other painful diseases)

SvarTz, N. (1971) 'Macroglobulins, provoking Haemagglutination in Rheumatoid Arthritis and Other Diseases'. Almqvist and Wiksell, Stockholm

Sheldon, W. H., DupertuIs, C. W., AND MCDermotr, E. (1954) 'Atlas of Men'. Harper, New York

Sichère, R. M., AND HuCKel, G. (1971). Cahiers Rééd. Réadapt., 6, 161 (Kinésithérapie et rhumatisme inflammatoire)

TAPanes, F. J., Rawson, A. J., AND Hollander, J. L. (1972) Arthr. and Rheum., 15, 153 (Serum anti-immunoglobulins in psoriatic arthritis as compared with rheumatoid arthritis)

Waller, M. V. (1968) In 'Population Studies of the Rheumatic Diseases: Proc. III int. Symp., New York, 1966', ed. P. H. Bennett and P. H. N. Wood, p. 190. Int. Congr. Ser. No. 148. Excerpta Medica Foundation, Amsterdam

WARD, D. J. (1971) Brit. med.J., 2, 297 (Rheumatoid arthritis and personality: a controlled study)

WIIDE, G. J. S. (1963) 'Neurotische labiliteit gemeten volgens de vragenlijstmethode'. F. van Rossen, Amsterdam

WoLfF, B. B. (1971-1972) Bull. rheum. Dis., 22, 656 (Current psychological concepts in rheumatoid arthritis) 